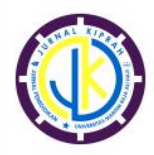

\title{
PENGEMBANGAN LEMBAR KERJA MAHASISWA BERBANTUAN GAMES PADA MATAKULIAH FISIKA DASAR DI PROGRAM STUDI PENDIDIKAN BIOLOGI
}

\author{
Okta Alpindo $^{1^{*}}$, Dodi Dahnuss ${ }^{2}$ \\ ${ }^{1,2}$ Universitas Maritim Raja Ali Haji, Tanjungpinang, Kepulauan Riau 29124 Indonesia
}

Pengiriman: 2 Oktober 2019; Diterima: 4 November 2019; Publikasi: 27 November 2019

\begin{abstract}
Abstrak
Sudah seharusnya Fisika dipelajari dengan cara menyenangkan. Cara penyampaian materi akan sangat berpengaruh terhadap proses dan hasil pembelajaran Fisika. Namun fakta yang ditemui dilapangan pelajaran Fisika sangat membosankan bagi mahasiswa pendidikan Biologi. Sehingga motivasi mahasiswa saat belajar Fisika sangat rendah. Padahal pelajaran Fisika sangat dibutuhkan oleh mahasiswa Pendidikan Biologi karena Mahasiswa pendidikan Biologi akan melaksanakan Praktek Lapangan di Sekolah Menengah Pertama yang mana pelajaran Ilmu Pengetahuan Alam sudah berbentuk keterpaduan. Jadi, sangat penting sekali bagi mahasiswa Pendidikan Biologi memahami mata kuliah Fisika. Oleh karena itu dalam penelitian ini dibuat Lembar Kerja Mahasiswa berbantuan games pada mata kuliah Fisika program studi pendidikan Biologi untuk meningkatkan motivasi belajar mahasiswa. Tujuan dari penelitian ini adalah mengembangkan lembar kerja mahasiswa berbantuan games yang valid, praktis dan efektif. Metode penelitian menggunakan uji validitas, praktikalitas dan efektivitas melalui instrumen yang telah divalidasi oleh ahli. Setelah dilakukan penelitian didapatkan hasil bahwa lembar kerja mahasiswa yang dikembangkan telah valid, praktis dan efektif dalam meningkatkan motivasi belajar mahasiswa.
\end{abstract}

Kata kunci: LKM; games; motivasi

\begin{abstract}
Physics should be learned in a fun way. How the material is delivered will greatly affect the process and results of physics learning. But the facts found in the field of physics lessons are very boring for Biology education students. So the motivation of students when studying Physics is very low. Even though Physics is very much needed by Biology Education students because Biology Education students will carry out Field Practices in junior high schools where natural science lessons are already integrated. So, it is very important for Biology Education students to understand Physics courses. Therefore in this study a Student's Worksheet is assisted by games in the Physics course in Biology education study programs to increase student motivation. The purpose of this study is to develop worksheets assisted by games that are valid, practical and effective. The research method uses the validity, practicality and effectiveness test through instruments that have been validated by experts. After doing research, it was found that the student worksheets developed were valid, practical and effective in increasing student motivation.
\end{abstract}

Keywords: worksheet; games; motivation

\section{Pendahuluan}

Pesatnya perkembangan teknologi memberikan banyak kemudahan dalam berbagai

${ }^{*}$ Penulis Korespondensi

Email Address : oktaalpindo@umrah.ac.id segi kehidupan termasuk dalam dunia pendidikan. Pendidikan memegang peranan yang sangat penting untuk menghasilkan Sumber 
JURNAL KIPRAH. November 2019; 7 (2): 117-124

ISSN (online): 2580-6947

ISSN (print): 2354-7278

Daya Manusia (SDM) yang berkualitas. Pendidikan harus mampu memberi solusi dalam upaya memajukan dan memenangkan kompetensi dalam persaingan secara global. Seperti yang dijelaskan dalam UU Sistem Pendidikan Nasional No. 20 tahun 2003 bahwa: Pendidikan merupakan usaha sadar dan terencana untuk mewujudkan suasana belajar dan proses pembelajaran agar Mahasiswa secara aktif mengembangkan potensi dirinya untuk memiliki kekuatan spiritual keagamaan, pengendalian diri, kepribadian, kecerdasan, akhlak mulia serta keterampilan yang diperlukan dirinya, masyarakat, bangsa dan negara.

Oleh karena itu bidang pendidikan perlu mendapat perhatian dan penanganan yang intensif baik dari pemerintah, masyarakat maupun pengelola pendidikan. Berbagai perangkat pendidikan dan sarana pendidikan yang modern turut mendukung optimalisasi proses pembelajaran baik di tingkat sekolah maupun di kehidupan sehari-hari. Dampak perkembangan IPTEK terhadap proses pembelajaran adalah diperkayanya sumber dan media pembelajaran seperti buku teks, film, video, telivisi, slide, hypertext, dan web. Dosen profesional dituntut mampu memilih dan menggunakan berbagai jenis media pembelajaran yang ada disekitarnya. Pendidikan juga harus mampu beradaptasi mengikuti perkembangan teknologi yang ada. Munculnya berbagai aplikasi teknologi yang menekankan pada aspek komunikasi, diharapkan dapat membantu dalam menyelesaikan berbagai masalah pembelajaran pada semua mata pelajaran, termasuk mata pelajaran Fisika.

Fisika merupakan salah satu cabang sains yang mendasari perkembangan ilmu pengetahuan dan kemajuan teknologi serta konsep hidup yang harmonis dengan alam. Fisika mengkaji fakta-fakta dan prinsip-prinsip yang ada pada fenomena alam dan memberi wawasan tentang cara memperoleh fakta dan prinsip tersebut. Fisika berkaitan dengan cara mencari tahu tentang fenomena alam secara sistematis, sehingga Fisika bukan hanya penguasaan kumpulan pengetahuan yang berupa fakta-fakta, konsep-konsep, atau prinsip-prinsip saja tetapi merupakan suatu proses penemuan. Menurut Dwijananti dan Yulianti (2010) Lembar Kerja Mahasiswa (LKM) dapat membantu Mahasiswa aktif mempresentasikan dan melakukan diskusi untuk memecahakan masalah, serta menarik kesimpulan melalui proses berpikir kritis. Hasil penelitian menunjukkan kemampuan berpikir kritis mahasiswa yang dapat dikembangkan pada model pembelajaran ini adalah: mengklasifikasi, mengasumsi, memprediksi, menghipotesis, mengevaluasi, menganalisis, dan membuat kesimpulan. Sementara Cahyani (2016) berpendapat bawa penggunaan LKM memberikan respon positif dari mahasiswa dan juga meningkatkan hasil belajar mahasiswa. Jadi, LKM dapat membantu mahasiswa berperan lebih aktif dan meningkatkan hasil belajar mahasiswa.

Cara penyampaian materi akan sangat berpengaruh terhadap proses dan hasil pembelajaran Fisika. Namun fakta yang ditemui dilapangan pelajaran Fisika sangat membosankan bagi mahasiswa pendidikan Biologi. Berdasarkan angket motivasi belajar yang disebarkan, $76 \%$ mahasiswa biologi menyatakan bahwa pelajaran Fisika itu susah dan 63\% menyatakan bah pelajaran Fisika membosankan. Sehingga dapat disimpulkan bahwa motivasi mahasiswa saat belajar Fisika sangat rendah. Padahal pelajaran Fisika sangat dibutuhkan oleh mahasiswa Pendidikan Biologi karena Mahasiswa pendidikan Biologi akan melaksanakan Praktek Lapangan di SMP. Pelajaran IPA SMP sudah berbentuk keterpaduan. Jadi, sangat penting sekali bagi mahasiswa Pendidikan Biologi memahami mata kuliah Fisika. Menurut Aristini (2013) salah satu upaya yang dapat meningkatkan motivasi belajar peserta didik adalah dengan mengkombinasikan pelajaran dengan games. Sementara Boyle, dkk (2016) menyatakan bahwa Hasil yang paling sering terjadi yang dilaporkan untuk game untuk pembelajaran adalah perolehan pengetahuan, sementara game hiburan membahas jangkauan 
yang lebih luas dari afektif, perubahan perilaku, persepsi dan kognitif serta hasil fisiologis.

Jadi dalam penelitian ini dibuat Lembar Kerja Mahasiswa (LKM) berbantuan games pada mata kuliah Fisika program studi pendidikan Biologi untuk meningkatkan motivasi belajar mahasiswa.

\section{Metode Penelitian}

Jenis penelitian yang dilakukan adalah penelitian dan pengembangan (Research and Development). Sugiyono (2010) mengemukakan "Penelitian dan pengembangan adalah metode penelitian yang digunakan untuk menghasilkan produk tertentu dan menguji kepraktisan produk tersebut". Produk yang dihasilkan dalam penelitian ini adalah LKM berbantuan games.

Populasi dalam penelitian ini adalah mahasiswa Semester 2 Program Studi Pendidikan Biologi yang terdiri dari dua kelas. Pengambilan sampel dilakukan dengan teknik simple random sampling.

Instrumen yang digunakan untuk mengumpulkan data dalam penelitian ini adalah instrumen pada tahap analisis masalah, instrumen validasi, dan instrumen praktikalitas.

Instrumen analisis masalah menggunakan angket untuk melihat motivasi belajar peserta didik. Angket motivasi belajar dapat dilihat pada Tabel 1.

Tabel 1 Angket Motivasi Belajar

\begin{tabular}{|l|l|}
\hline No & \multicolumn{1}{|c|}{ Pernyataan } \\
\hline 1 & $\begin{array}{l}\text { Saya mengerjakan tugas Fisika dengan } \\
\text { sungguh-sungguh. }\end{array}$ \\
\hline 2 & $\begin{array}{l}\text { Saya menyelesaikan tugas Fisika dengan } \\
\text { tepat waktu. }\end{array}$ \\
\hline 3 & $\begin{array}{l}\text { Bagi saya yang terpenting adalah } \\
\text { mengerjakan soal atau tugas tepat waktu } \\
\text { tanpa peduli dengan hasil yang akan saya } \\
\text { peroleh. }\end{array}$ \\
\hline 4 & $\begin{array}{l}\text { Setiap ada tugas Fisika saya langsung } \\
\text { mengerjakannya. }\end{array}$ \\
\hline 5 & $\begin{array}{l}\text { Saya tidak serius dalam mengerjakan soal } \\
\text { maupun tugas yang diberikan oleh dosen. }\end{array}$ \\
\hline 6 & Jika ada soal yang sulit maka saya tidak \\
\hline
\end{tabular}

\begin{tabular}{|c|c|}
\hline & akan mengerjakannya. \\
\hline 7 & $\begin{array}{l}\text { Apabila saya menemui soal yang sulit } \\
\text { maka saya akan berusaha untuk } \\
\text { mengerjakan sampai saya menemukan } \\
\text { jawabannya. }\end{array}$ \\
\hline 8 & $\begin{array}{l}\text { Saya selalu mendengarkan penjelasan } \\
\text { dosen dengan baik. }\end{array}$ \\
\hline 9 & $\begin{array}{l}\text { Saya lebih senang berbicara sendiri } \\
\text { dengan teman dan tidak mendengarkan } \\
\text { pada saat dosen menjelaskan. }\end{array}$ \\
\hline 10 & $\begin{array}{l}\text { Saya selalu bertanya kepada dosen } \\
\text { mengenai materi yang belum saya } \\
\text { pahami. }\end{array}$ \\
\hline 11 & $\begin{array}{l}\text { Saya malas bertanya kepada dosen } \\
\text { mengenai materi yang tidak saya pahami. }\end{array}$ \\
\hline 12 & $\begin{array}{l}\text { Saya selalu menjawab pertanyaan yang } \\
\text { diajukan oleh dosen. }\end{array}$ \\
\hline 13 & $\begin{array}{l}\text { Saya lebih senang mengerjakan tugas } \\
\text { Fisika bersama dengan teman }\end{array}$ \\
\hline 14 & $\begin{array}{l}\text { Saya senang belajar Fisika karena dosen } \\
\text { mengajar dengan menggunakan berbagai } \\
\text { cara. }\end{array}$ \\
\hline 15 & $\begin{array}{l}\text { Menurut saya kegiatan belajar Fisika } \\
\text { membosankan karena dosen hanya } \\
\text { menjelaskan materi dengan berceramah } \\
\text { saja. }\end{array}$ \\
\hline 16 & $\begin{array}{l}\text { Saya senang belajar Fisika karena dosen } \\
\text { menggunakan permainan dalam } \\
\text { pembelajaran. }\end{array}$ \\
\hline 17 & $\begin{array}{l}\text { Saya senang belajar Fisika karena pada } \\
\text { saat pembelajaran dibentuk kelompok- } \\
\text { kelompok. }\end{array}$ \\
\hline 18 & $\begin{array}{l}\text { Apabila dalam buku ada soal yang belum } \\
\text { dikerjakan maka saya akan } \\
\text { mengerjakannya. }\end{array}$ \\
\hline 19 & $\begin{array}{l}\text { Saya mencari sumber-sumber lain yang } \\
\text { sesuai untuk menyempurnakan tugas yang } \\
\text { saya kerjakan. }\end{array}$ \\
\hline 20 & $\begin{array}{l}\text { Saya lebih senang mengerjakan soal yang } \\
\text { mudah dari pada yang sulit }\end{array}$ \\
\hline
\end{tabular}

Instrumen validitas pengembangan LKM berbantuan games berisikan indikator yang akan dinilai validator yaitu: kelengkapan LKM, kelayakan isi LKM, penggunaan bahasa pada LKM, dan penyajian LKM. Secara lebih rinci dapat dilihat pada Tabel 2. 
JURNAL KIPRAH. November 2019; 7 (2): 117-124

ISSN (online): 2580-6947

ISSN (print): 2354-7278

Tabel 2. Lembar Validasi Isi LKM

\begin{tabular}{|c|c|}
\hline No & Indikator Penilaian \\
\hline 1 & $\begin{array}{l}\text { Topik yang disajikan dalam LKM } \\
\text { sudah sesuai dengan tuntutan } \\
\text { indikator yang dirumuskan. }\end{array}$ \\
\hline 2 & $\begin{array}{l}\text { LKM menyajikan informasi singkat } \\
\text { yang sesuai dengan deskripsi materi } \\
\text { pembelajaran. }\end{array}$ \\
\hline 3 & $\begin{array}{l}\text { Kegiatan dan pengamatan dikaitkan } \\
\text { dengan kehidupan nyata peserta } \\
\text { didik dan teknologi. }\end{array}$ \\
\hline 4 & $\begin{array}{l}\text { Langkah diskusi dalam } \text { LKM } \\
\text { mendorong peserta } \\
\text { membangun kepercayaandirinya }\end{array}$ \\
\hline 5 & $\begin{array}{l}\text { Kegiatan dalam LKM mendorong } \\
\text { peserta didik belajar secara ilmiah. }\end{array}$ \\
\hline 6 & $\begin{array}{l}\text { LKM disusun sesuai dengan model } \\
\text { pembelajaran yang jelas }\end{array}$ \\
\hline 7 & $\begin{array}{l}\text { Materi dalam LKM yang memuat } \\
\text { penjelasan yang penting mengenai } \\
\text { materi usaha dan energi }\end{array}$ \\
\hline 8 & $\begin{array}{l}\text { LKM memuat daftar pertanyaan } \\
\text { yang berhubungan dengan konsep } \\
\text { dan materi yang disajikan. }\end{array}$ \\
\hline 9 & $\begin{array}{l}\text { Pertanyaan membantu peserta didik } \\
\text { dalam membuat kesimpulan dan } \\
\text { mengaplikasikan pengetahuan yang } \\
\text { telah mereka bangun. }\end{array}$ \\
\hline
\end{tabular}

Tabel 3. Lembar Validasi Konstruksi LKM

\begin{tabular}{|c|l|}
\hline No & \multicolumn{1}{|c|}{ Indikator Penilaian } \\
\hline 1 & $\begin{array}{l}\text { Penyajian LKM materi usaha dan } \\
\text { energi, dimulai dari: Cover LKM, } \\
\text { Identitas LKM, KI, KD, tujuan } \\
\text { diskusi, susunan LKM sesuai model } \\
\text { yang diterapkan. }\end{array}$ \\
\hline 2 & $\begin{array}{l}\text { Konsisten dalam menggunakan } \\
\text { simbol/lambang }\end{array}$ \\
\hline 3 & $\begin{array}{l}\text { LKM menggunakan warna-warna } \\
\text { yang menarik }\end{array}$ \\
\hline 4 & $\begin{array}{l}\text { LKM menyajikan gambar yang } \\
\text { menarik }\end{array}$ \\
\hline 5 & $\begin{array}{l}\text { LKM menggunakan font yang jelas } \\
\text { dan terbaca }\end{array}$ \\
\hline 6 & $\begin{array}{l}\text { LKM mempunyai tata letak dan lay } \\
\text { out teratur }\end{array}$ \\
\hline 7 & $\begin{array}{l}\text { LKM mempunyai desain tampilan } \\
\text { sederhana dan menarik }\end{array}$ \\
\hline 8 & $\begin{array}{l}\text { LKM memiliki daftar pustaka yang } \\
\text { jelas. }\end{array}$ \\
\hline
\end{tabular}

Tabel 4. Lembar Validasi Bahasa LKM

\begin{tabular}{|l|l|}
\hline No & \multicolumn{1}{|c|}{ Indikator Penialian } \\
\hline 1 & Bahasa yang digunakan komunikatif \\
\hline 2 & $\begin{array}{l}\text { Bahasa yang digunakan memotivasi } \\
\text { peserta didik untuk melakukan } \\
\text { pekerjaan }\end{array}$ \\
\hline 3 & $\begin{array}{l}\text { Bahasa yang digunakan tidak } \\
\text { bermakna ganda }\end{array}$ \\
\hline 4 & $\begin{array}{l}\text { Bahasa yang digunakan merupakan } \\
\text { bahasa baik dan benar menurut } \\
\text { kaidah tata bahasa Indonesia }\end{array}$ \\
\hline 5 & \begin{tabular}{l} 
Informasi yang disampaikan jelas \\
Ejaan yang digunakan mengacu pada \\
\hline 7
\end{tabular} \\
\hline $\begin{array}{l}\text { Konsisten dalam menggunakan } \\
\text { istilah yang menggambarkan konsep }\end{array}$ \\
\hline
\end{tabular}

Lembar validasi tersebut diberikan kepada ahli (validator) bersama dengan LKM yang akan divalidasi. Hal ini bertujuan untuk memperoleh masukan atau penilaian terhadap LKM tersebut.

Instrumen praktilitas berupa angket digunakan untuk mengumpulkan informasi tentang praktikalitas LKM berbantuan games. Angket praktikalitas diberikan kepada peserta didik untuk mengetahui sejauh mana kemudahan penggunaan LKM berbantuan games yang dibuat. Angket praktikalitas dapat dilihat pada Tabel 5.

Tabel 5. Lembar Praktikalitas LKM

\begin{tabular}{|c|l|}
\hline No & \multicolumn{1}{|c|}{ Aspek yang Dinilai } \\
\hline A. MUDAH DIPAHAMI \\
\hline 1 & $\begin{array}{l}\text { Materi yang ada pada LKM ini jelas dan } \\
\text { mudah dipahami }\end{array}$ \\
\hline 2 & $\begin{array}{l}\text { Materi usaha dan energi yang ada pada } \\
\text { LKM menuntun Saya untuk } \\
\text { menemukan konsep dan prinsip Fisika } \\
\text { pada kehidupan sehari-hari }\end{array}$ \\
\hline 3 & $\begin{array}{l}\text { Lembar Kegiatan pada LKM ini } \\
\text { memudahkan Saya dalam kegiatan } \\
\text { diskusi dan percobaan }\end{array}$ \\
\hline 4 & $\begin{array}{l}\text { Tugas yang ada di LKM ini mudah } \\
\text { Saya pahami }\end{array}$ \\
\hline 5 & Rangkuman yang ada pada LKM ini \\
\hline
\end{tabular}




\begin{tabular}{|c|l|}
\hline & mudah Saya pahami \\
\hline 6 & $\begin{array}{l}\text { Evaluasi yang ada pada LKM mudah } \\
\text { Saya pahami }\end{array}$ \\
\hline B. MENARIK \\
\hline 7 & $\begin{array}{l}\text { Komposisi warna pada LKM menarik } \\
\text { untuk dibaca }\end{array}$ \\
\hline 8 & $\begin{array}{l}\text { Materi usaha dan energi yang ada pada } \\
\text { LKM ini membuat Saya senang dalam } \\
\text { belajar Fisika }\end{array}$ \\
\hline 9 & $\begin{array}{l}\text { Materi yang ada pada LKM menarik } \\
\text { untuk dipelajari }\end{array}$ \\
\hline 10 & $\begin{array}{l}\text { Kelengkapan materi yang ada pada } \\
\text { LKM ini menambah wawasan dan } \\
\text { informasi Saya dalam belajar Fisika }\end{array}$ \\
\hline C. EFISIEN untuk \\
\hline 11 & $\begin{array}{l}\text { Waktu yang dibutuhkan } \\
\text { memahami LKM tidak terlalu lama }\end{array}$ \\
\hline 12 & $\begin{array}{l}\text { Saya dapat belajar Fisika dengan } \\
\text { menggunakan LKM ini meskipun tidak } \\
\text { ada teman maupun guru }\end{array}$ \\
\hline 13 & $\begin{array}{l}\text { LKM dapat digunakan untuk melatih } \\
\text { kemandirian Saya dalam belajar }\end{array}$ \\
\hline \multicolumn{1}{|c|}{ Teknik analisis data yang digunakan } \\
adalah analisis deskriptif yang menggambarkan \\
validitas dan praktikalitas LKM berbantuan \\
games. \\
\hline
\end{tabular}

Analisis awal digunakan untuk mengetahui permasalahan awal sehingga dibutuhkan suatu pengembangan. Beberapa aktivitas penting yang dilakukan pada tahap ini, yaitu analisis motivasi belajar dan analisis materi pembelajaran.

Kategori analisis motivasi belajar diperoleh dengan cara menghitung skor dari setiap responden. Skor setiap responden diperoleh menggunakan persamaan:

$$
\mathrm{S}_{\mathrm{k}}=\frac{\Sigma X_{i}}{X_{\max }} \times 100
$$

Keterangan:

$$
\begin{array}{ll}
\mathrm{S}_{\mathrm{k}} & \text { : skor yang diperoleh } \\
\mathrm{X}_{\mathrm{i}} & \text { : skor setiap responden } \\
\mathrm{X}_{\max } & : \text { skor maksimum dari angket } \\
\text { untuk setiap indikator. }
\end{array}
$$

Analisis data awal akhir untuk setiap indikator menggunakan ketentuan pada Tabel 6 .
Tabel 6. Kategori Analisis Motivasi Belajar

\begin{tabular}{|c|c|}
\hline Interval (\%) & Kategori \\
\hline $0-20$ & Tidak baik \\
\hline $21-40$ & Kurang baik \\
\hline $41-60$ & Cukup baik \\
\hline $61-80$ & Baik \\
\hline $81-100$ & Sangat baik \\
\hline
\end{tabular}

Menurut Penfield \& Giacobbi (2004)

Analisis validitas dapat menggunakan menggunakan rumus Aiken's V yaitu:

$$
V=\frac{\sum s}{[n(c-1)]}
$$

\section{Keterangan:}

$\mathrm{s}=\mathrm{r}-\mathrm{lo}$

lo = Angka penilaian validitas yang terendah (dalam hal ini $=1$ )

$\mathrm{c}=$ Angka penilaian validitas yang tertinggi (dalam hal ini $=4)$

$\mathrm{r}$ = Angka yang diberikan oleh seorang penilai

Kategori validitas $L K M$ berdasarkan nilai akhir yang diperoleh dapat dilihat pada Tabel 7.

Tabel 7. Kategori Validitas Produk

\begin{tabular}{|c|c|}
\hline Tingkat Pencapaian & Kategori \\
\hline$\geq 0,6$ & Valid \\
\hline$<0,6$ & Tidak valid \\
\hline
\end{tabular}

(Azwar.2012)

$$
\text { Kepraktisan produk dianalisis }
$$

berdasarkan angket yang telah diisi oleh guru. Analisis data angket praktikalitas produk menggunakan Skala Likert dengan menggunakan persamaan

$$
P=\frac{f}{N} \times 100 \%
$$

Dimana :

$\mathrm{P}=$ Nilai akhir

$f=$ Perolehan skor

$\mathrm{N}=$ Skor maksimum

Kategori kepraktisan menurut Riduwan (2008) dapat dilihat pada Tabel 8 .

Tabel 8. Tabel Kategori Kepraktisan

\begin{tabular}{|c|c|c|}
\hline No & Nilai & Kriteria \\
\hline 1 & $80 \%<\mathrm{x} \leq 100 \%$ & Sangat praktis \\
\hline 2 & $60 \%<\mathrm{x} \leq 80 \%$ & Praktis \\
\hline 3 & $40 \%<\mathrm{x} \leq 60 \%$ & Cukup praktis \\
\hline 4 & $20 \%<\mathrm{x} \leq 40 \%$ & Kurang praktis \\
\hline 5 & $0 \%<\mathrm{x} \leq 20 \%$ & Tidak praktis \\
\hline
\end{tabular}


JURNAL KIPRAH. November 2019; 7 (2): 117-124

ISSN (online): 2580-6947

ISSN (print): 2354-7278

\section{Hasil dan Pembahasan}

Hasil Uji Validitas

Uji validitas terdiri dari validitas isi, konstruksi dan bahasa dengan hasil sebagai berikut :

Tabel 9. Hasil uji validitas LKM

\begin{tabular}{|l|l|l|l|l|}
\hline \multicolumn{1}{|c|}{$\begin{array}{c}\text { Aspek } \\
\text { Validasi }\end{array}$} & Ahli & Kategori & Praktisi & Kategori \\
\hline Isi & 0,78 & Valid & 0,88 & Valid \\
\hline Konstruksi & 0,79 & Valid & 0,77 & Valid \\
\hline Bahasa & 0,77 & Valid & 0,89 & Valid \\
\hline
\end{tabular}

Hasil validitas Lembar kerja pada aspek isi memiliki rata-rata 0,78 yang berada pada kategori valid. Hasil validitas bahan ajar dari aspek konstruksi memiliki nilai 0,79 dengan kategori valid. Validitas bahasa berdasarkan hasil penelitian yang telah dilakukan didapatkan bahwa LKM berbantuan games yang dikembangkan valid. Berdasarkan paparan pada hasil penelitian didapatkan bahwa bahasa pada LKM berbantuan games sudah berada pada tingkat yang sesuai dan diatas 0,6 dengan ratarata nilai $\mathrm{V} 0,76$. Validator berpendapat bahwa LKM berbantuan games tidak perlu lagi direvisi dari segi bahasa. Dengan demiikian, dapat disimpulkan bahwa LKM berbantuan games sudah valid menurut tenaga ahli. Sementara itu, validasi oleh praktisi didapatkan hasil 0,88 untuk aspek bahasa, 0,77 untuk aspek konstruksi dan 0,89 untuk aspek isi. Jadi, LKM berbantuan games juga berada pada kategori valid menurut praktisi.

\section{Hasil Uji Praktikalitas}

Hasil praktikalitas didapat melalui angket yang diberikan kepada dosen dan seluruh mahasiswa di kelas penelitian yang bersangkutan untuk mengetahui tingkat kepraktisan bahan ajar yang dikembangkan. Hasil uji praktikalitas dapat dilihat pada Tabel 5.

Tabel 10 Hasil Analisis Angket Respon Peserta

Didik

\begin{tabular}{|c|c|c|c|}
\hline No & Praktisi & $\begin{array}{c}\text { Rata-Rata } \\
(\%)\end{array}$ & Kategori \\
\hline 1 & Dosen & 76,8 & Praktis \\
\hline 2 & Mahasiswa & 80,05 & Praktis \\
\hline \multicolumn{2}{|c|}{ Rata-rata } & 78,43 & Praktis \\
\hline
\end{tabular}

Uji praktikalitas dilakukan untuk mengetahui tingkat kepraktisan dari bahan ajar. Kepraktisan Lembar kerja mahasiswa dilihat dari menarik, efisien dan mudah dipahaminya bahan ajar tersebut. Uji praktikalitas berfungsi untuk melihat sejauh mana (pendidik/peserta didik) dan ahli lainnya mempertimbangkan intervensi apakah sebuah produk menarik dan dapat digunakan dalam kondisi normal. Uji kepraktisan LKM berbantuan games dilakukan pada uji lapangan di Program Studi Pendidikan Biologi. Hasil uji kepraktisan LKM berbantuan games respon dosen berada pada nilai $76,8 \%$ dengan kategori praktis. Dengan hasil ini dapat dinyatakan bahwa Lembar kerja mahasiswa menarik, efisien dan mudah dipahami oleh pendidik yang menggunakan bahan ajar tersebut.

Uji respon mahasiswa dilakukan untuk mengetahui tingkat kepraktisan dari LKM berbantuan games yang dikembangkan. Uji respon peserta didik dilakukan ketika peserta didik telah menggunakan seluruh bahan ajar yang dikembangkan di dalam proses pembelajaran. Adapun hasil uji kepraktisan bahan ajar berada pada kategori praktis dengan nilai $80,05 \%$. Berdasarkan pernyataan tersebut dapat disimpulkan bahwa dari semu kriteria uji kepraktisan lembar kerja mahasiswa berada pada kategori praktis.

\section{Hasil Uji Efektivitas}

Hasil uji efektivitas didapat melalui penyebaran angket motivasi belajar mahasiswa sebelum dan setelah serta nilai pretes dan postes menggunakan LKM berbantuan games. Perbandingan nilai motivasi belajar mahasiswa sebelum dan sesudah menggunakan LKM dapat dilihat pada Gambar 1. 


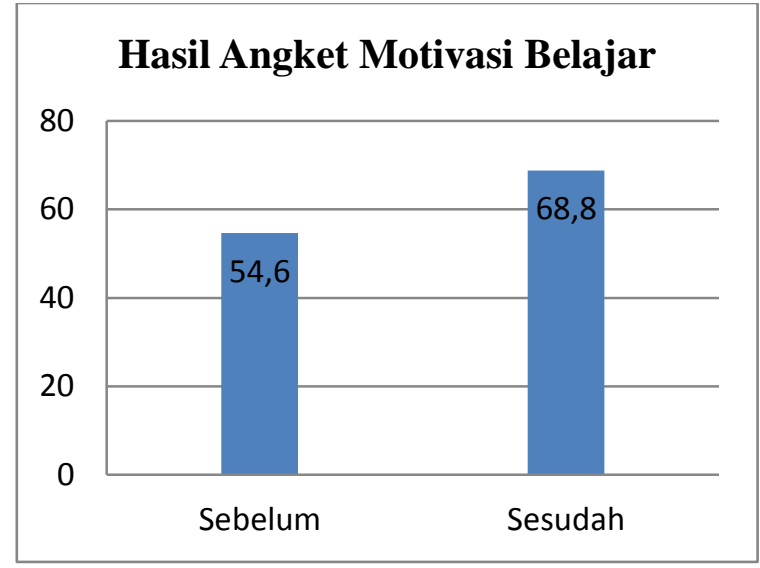

Gambar 1 Hasil Angket Motivasi Belajar

Menurut Prastowo (2014) sebuah bahan ajar dikatakan efektif apabila setelah pembelajaran menggunakan bahan ajar terdapat dampak positif terhadap peserta didik. Berdasarkan uji coba lapangan yang telah dilakukan didapatkan bahwa Lembar kerja mahasiswa berbantuan games efektif dalam meningkatkan motivasi belajar mahasiswa karena terjadi peningkatan persentase motivasi belajar mahasiswa. Namun demikian, masih ada beberapa peserta didik yang belum mencapai nilai yang diinginkan. Hal ini disebabkan oleh kemampuan pemahaman setiap peserta didik terhadap materi berbeda-beda. Jadi, kemampuan adaptasi peserta didik dalam belajar berbeda menyebabkan hasil yang didapat setiap peserta didik juga berbeda. Dari tabel hasil analisis peningkatan nilai mahasiswa terlihat bahwa secara kesuluran mengalami peningkatan.

\section{Kesimpulan}

Berdasarkan prosedur penelitian pengembangan yang telah dilakukan, diperoleh kesimpulan: dari data validitas dapat disimpulkan bahwa lembar kerja mahasiswa yang dikembangkan mempunyai nilai rata-rata 0,78 dari ahli dan 0,85 dari praktisi. Kedua nilai tersebut berada pada kategori valid. Hasil penelitian menunjukkan kepraktisan lembar kerja mahasiswa respon dosen berada pada nilai 76,8\% dengan kategori praktis. Kepraktisan lembar kerja mahasiswa respon peserta didik berada pada kategori praktis dengan nilai $80,05 \%$. Lembar kerja mahasiswa efektif dalam meningkatkan motivasi belajar mahasiswa karena terdapat peningkatan persentasi motivasi dan nilai belajar

\section{Ucapan Terimakasih}

Artikel ini merupakan publikasi hasil penelitian dengan skema Penelitian Dosen Muda Tahun 2019 menggunakan dana yang bersumber dari Hibah Internal UMRAH. Oleh karena itu penulis mengucapkan terimakasih kepada Hibah Internal UMRAH atas dukungan pendanaannya demi kesuksesan penelitian ini.

\section{Referensi}

Aristin, N.I, dan Z, Abidin. 2013. Penerapan Pembelajaran TGT Berbantuan Game Edukasi Terhadap Kemampuan Memecahkan Masalah Siswa. JURNAL KREANO, ISSN : 2086-2334, Volume 4 Nomor 1

Azwar, S. (2012). Reliabiltas dan Validitas. Edisi 4. Yogyakarta : Pustaka Pelajar

Boyle, Elizabeth A. dkk. 2016. An update to the systematic literature review of empirical evidence of the impacts and outcomes of computer games and serious games. Computers and Education. DOI : 10.1016/j.compedu.2015.11.003

Cahyani, Dwi. dkk. 2016. Pengembangan lembar kerja mahasiswa pada mata kuliah struktur aljabar untuk mahasiswa STKIP PGRI Pacitan. Humaniora.

Dwijananti, P dan Yulianti, D. 2010. Pengembangan Kemampuan Berpikir Kritis Mahasiswa Melalui Pembelajaran Problem Based Instruction Pada Mata Kuliah Fisika Lingkungan. Jurnal Pendidikan Fisika Indonesia. DOI: 10.15294/jpfi.v6i2.1122

Penfield \& Giacobbi. 2004. Applying a score confidence interval to Aiken's item content-relevance index. Measurement in Physical Education and Exercise Science. DOI :10.1207/s15327841mpee0804_3

Prastowo, Andi. 2014. Pengembangan Bahan Ajar Tematik. Jakarta : Prenadamedia 
JURNAL KIPRAH. November 2019; 7 (2): 117-124

ISSN (online): 2580-6947

ISSN (print): 2354-7278

Group

Riduwan. 2008. Variabel-Variabel Penelitian.

Bandung: Alfabeta.

Sugiyono. 2010. Metode Penelitian Kuantitatif, Kualitatif dan $R \& D$. Bandung: Alfabeta

UU Sistem Pendidikan Nasional No. 20 tahun

2003 